\title{
ALTMAN MODEL VERIFICATION USING A MULTI-CRITERIA APPROACH FOR SLOVAKIAN AGRICULTURAL ENTERPRISES
}

\section{Roman Vavrek ${ }^{1}$, Petra Gundová2, Ivana Kravčáková Vozárová3, Rastislav Kotulič ${ }^{4}$}

\footnotetext{
1 Technical University of Liberec, Faculty of Economics, Department of Informatics, Czech Republic, ORCID: 0000-0002-6047-9434, vavrek.roman@gmail.com;

2 Matej Bel University in Banská Bystrica, Faculty of Economics, Department of Corporate Economics and Management, Slovakia, ORCID: 0000-0003-2335-0073, petra.gundova@umb.sk;

3 University of Prešov, Faculty of Management, Department of Economics and Economy, Slovakia, ORCID: 0000-0002-3056-5294, ivana.kravcakova.vozarova@unipo.sk;

4 University of Prešov, Faculty of Management, Department of Economics and Economy, Slovakia, ORCID: 0000-0002-8341-3016, rastislav.kotulic@unipo.sk.
}

\begin{abstract}
The Altman model is still one of the most widely used predictive models in the 21st century, and it aims to highlight the differences between bankrupt and healthy enterprises. This model has been modified several times; its most well-known forms are from 1968, 1983 and 1995. However, the use of the Altman Z-score for Slovak enterprises is more than questionable. The unsuitability of the model for the conditions of Slovak companies has been confirmed by several empirical surveys. The objective of this study was to verify the validation of these three variants of the Altman model, depending on how an unprosperous company is identified, using a sample of 996 agricultural enterprises operating in the Slovak Republic. Four indicators were selected for the identification of an unprosperous enterprise - economic results, total liquidity, equity, and economic value added - and they were monitored over the last year or, as the case may be, over the last three years from 2014 to 2016. Using the Technique for Order of Preference by Similarity to Ideal Solution (TOPSIS) and Coefficient of variation (CV) methods as an objective method for weight determination, a combination of the Altman model from 1968 and the negative total liquidity in the last reference year was determined to be the best. One of our main findings is that the way in which an unprosperous enterprise is identified is a significant factor affecting the overall reliability of the Altman model. The Altman model from 1968 and 1983 confirmed the differences resulting from the natural conditions in which the enterprises operate. The economic results and economic value added (EVA) proved to be inappropriate as indicators for defining an unprosperous enterprise in the conditions of the Slovak Republic.
\end{abstract}

Keywords: Unprosperous enterprise, Altman model, TOPSIS technique, Coefficient of variation method.

JEL Classification: B23, Q14.

APA Style Citation: Vavrek, R., Gundová, P., Kravčáková Vozárová, I., \& Kotulič, R. (2021). Altman Model Verification Using a Multi-criteria Approach for Slovakian Agricultural Enterprises. E\&M Economics and Management, 24(1), 146-164. https://doi.org/10.15240/tul/001/2021-1-010

\section{Introduction}

In the 21st century, a prerequisite for a successful business is good knowledge of past and current trends, for the right long-term decisions to be made. According to Brealey et al. (2011), knowing where a company stands today is a necessary prelude to contemplating where the company might end up in the future. One of the options for supporting short-term and long-term decisions is financial analysis 
and financial ratios. Financial ratios have traditionally been indicators of a corporate's overall performance (Rahman et al., 2017) and may help to quantify the potential impact of internal ratings on financial performance (Belas et al., 2012; Klieštik et al., 2020).

The simplest and narrowest definition of financial analysis is based on the activities that this term includes without specifying their purpose, i.e., financial analysis is an analysis of company data, which is based on accounting (Sůvová \& Knaifl, 2008). It is focused on evaluating the financial health of a company and identifying its weaknesses and strengths (Mrkvička \& Kolář, 2006). According to Bank et al. (2006), this assessment is dependent on the company's liquidity and short-term financial liabilities, which represent its ability to regulate sources of funding. According to Bocharov (2007), it is necessary also to consider financial analysis in the long term, i.e., as a systematic process of controlling financial resources. From a time perspective, we can divide financial analysis into retrospective ex-post analysis and ex-ante analysis focusing on prediction. The latter can identify critical factors that could threaten the survival of an enterprise, i.e., an appropriate response to the results of ex-ante analysis in the form of recovery measures can significantly affect a company's future financial situation or ensure its sustainability. Financial distress can be defined in many different ways, and similarly, the terminology referring to companies experiencing such also differs - bankrupt, insolvent, and in default (Čámská \& Klecka, 2020; Alaka et al., 2018). Several prediction methods based on ex-ante financial analysis have been verified to date (e.g. Mihalovič, 2018; Gavúrová et al., 2017; Ko et al., 2017).

The aim of this study was to verify the explanatory power of three variants of the Altman model (from 1968, 1983 and 1995) depending on how a non-prosperous enterprise is identified, using a sample of 996 agricultural enterprises operating in Slovakia. To verify the outputs of ex-ante financial analysis, it is also necessary to identify prosperous and unprosperous enterprises (first part). There are usually two approaches, depending on the legislative and theoretical definitions. The legislative definition of an unprosperous enterprise is determined by the legislation of a given country; in this case, we encounter the concept of bankruptcy. The theoretical definition is given by the quantification of a selected set of financial indicators and their subsequent scaling (see ex ante methods). In the following text, the various approaches taken by both foreign and domestic authors to defining an unprosperous enterprise are described, and the frequent penetration of individual criteria can be observed. The second part is focused on a set of our own indicators used to identify an unprosperous enterprise, i.e., methodology. The third part describes the results of our own research, i.e., the verification of the predictive ability of the Altman model applied to a sample of 996 agricultural enterprises in the Slovak Republic. The use of a multi-criterion approach in the form of the CV-TOPSIS technique as a methodological extension to the discussed approaches to the verification of the explanatory power of prediction models can be described as original and new (see Part 1). The fourth part presents a discussion of the obtained results in the context of other authors' thoughts and research. The last part presents the conclusion and an evaluation of the obtained results.

\section{Different Approaches to Defining an Unprosperous Enterprise}

In the previous section, we dealt with defining an unprosperous enterprise from different perspectives, i.e., those that can be applied to enterprises regardless of the region in which they are located. For an appropriate definition, we consider it necessary also to take into account the local conditions in which a company operates. This is then reflected in a more precise definition of the conditions under which the enterprise can be considered unprosperous.

Bakeš and Valášková (2018) proposed criteria for identifying an unprosperous company that would take into account currently valid Slovak legislation along with economic and financial aspects. Such criteria include a ratio of equity to liabilities of $<0.08$, a total liquidity of $<1$, and negative earnings after tax. Durica (2018) described an unprosperous enterprise as an enterprise in crisis, when the total amount of their current liabilities is higher than the value of their current assets, the ratio of equity to liabilities is less than 0.04 , and the company has generated a loss (valid for analysis in 2016). Klieštik et al. (2018) and Mendelová and Bieliková (2017) identified an 
unprosperous enterprise as one that meets the criterion found in applicable legislation of the Slovak Republic, i.e., the value of its liabilities due exceeds the value of its assets, or the enterprise is in negative equity.

Bieliková et al. (2014) described a more complex view, expressed by three criteria according to which an enterprise can be considered unprosperous, namely, if it:

- Meets the legislative definition of an enterprise in the Slovak Republic, i.e., the enterprise is obliged to conduct accounting procedures according to a special regulation, it has more than one creditor and the value of its liabilities exceeds the value of its assets, i.e., the enterprise is in negative equity;

- Has made a loss for two consecutive years;

- Has a negative return on sales (ROS) and total liquidity $\left(L_{3}\right)$ less than 1 .

This set of criteria was also used by Bieliková (2016), who additionally take into account the following:

- The legislative definition of a company in prolongation in the Slovak Republic, i.e., the same criterion as in the previous case;

- The European Union guidelines 2004/C $244 / 02$ on state aid for rescuing and restructuring firms in difficulty, which define a firm in difficulty as one in which more than half of the basic capital is covered by loss and more than a quarter of that basic capital was covered by loss during the previous 12 months;

- A loss in two consecutive periods.

Bod'a and Úradníček (2016) and Král' et al. (2016) presented a set of three criteria for identifying an unsuccessful business. These criteria include negative equity and earnings after tax (EAT <0), as well as a total liquidity (L3) less than 1. According to Valášková et al. (2018a, 2018b), an unprosperous company is one with a ratio of equity to total debt less than 0.4 , a total liquidity (L3) less than 1 , and negative earnings after tax (EAT). According to Kováčová and Kubala (2018), it is an enterprise that:

- Did not achieve positive equity, or in other words, the difference between assets and liabilities, including the accrual of liabilities, was negative;

- Had at least two monetary liabilities more than 30 days overdue (because we were unable to identify this information directly from the financial statements, it has been replaced by a determination of the overall liquidity indicator threshold, i.e., $\mathrm{L}_{3}<1$ );

- Exhibited the following values for the selffinancing coefficient (equity and liabilities ratio): in 2016, <0.08; in 2015, <0.06; and in $2014,<0.04$.

For an independent group of authors, the key criterion for assessing business prosperity is the economic value added, which represents an aggregate characteristic of a company's financial performance. This group includes Šofranková et al. (2017), Neumaierová and Neumaier (2016), Čámská (2016), Maňasová (2008) and others; in all cases, an unprosperous enterprise is one that has achieved negative economic value added in a certain period. Along with Lesáková et al. (2015), Zalai et al. (2013) and others, we consider economic value added as an important criterion, as there has been a recent shift in thinking away from traditional indicators towards the market value of a company. This is confirmed by the fact that the EVA indicator is now increasingly being used in financial management and decisionmaking.

\section{The Altman Model as a Method of Multidimensional Discrimination Analysis}

As a result of the recent worldwide financial crisis and economic recession, the demand for bankruptcy-prediction models and financialrisk analysis has gained strong attention. The inability to accurately predict both bankruptcy and credit risk can have devastating socioeconomic effects (Antunes et al., 2017). To date, many models to predict bankruptcy have been introduced, but research in this field is ever constant (Le et al., 2018; Zelenkov et al., 2017). Several authors (Alaka et al., 2018; Karas \& Režnáková, 2012; Sušický, 2011) argue that methods of multidimensional discrimination analysis are the world's most widely used methods for predicting the financial health of businesses. Among their supporters are Balcaen and Oooghe (2006) and Sun et al. (2014), who appreciate their good classification capability.

The founder and pioneer of the use of multidimensional discrimination analysis is Altman (1968). The Altman Z-score is currently the most well-known and widely used prediction model (Gavúrová et al., 2017; Delina \& Packová, 
2013). It is often modified and verified for the needs of national economics. In the Slovak Republic, these applications are offered by Kabát (2011a) and Bod'a and Úradníček (2016, 2019); in the Czech Republic, by Schönfeld et al. (2018) and Režňáková and Karas (2015); and abroad, by Li and Faff (2019), Almany et al. (2016), Sulub (2014) and Lifschutz and Jacobi (2010).

The model was created using a sample of 33 US companies that went bankrupt between 1946 and 1965, while a second group included 33 US companies that prospered in this period (Kočišová \& Mišanková, 2014). Altman (2002) considered the limited data available to be a major problem, causing the group of selected businesses to be relatively heterogeneous. The author initially worked with a set of 22 selected financial indicators from five classes liquidity, profitability, debt, solvency and activity (Hosaka, 2019; Kabát, 2011a). Concerning Altman's Z-score, firms are grouped into the three zones of discrimination identified by Altman: the Distress Zone, Grey Zone and Safe Zone (Meggison et al., 2019). Altman's goal was to select a small number of ratio indicators that would best highlight the difference between a bankrupt and a healthy enterprise. Ratio indicators were selected based on the greatest differences in the values between the different sets of enterprises (see Tab. 1).

In this manner, Altman created a fivefactor model. In the original study from 1968, he successfully classified $94 \%$ of bankrupt US enterprises and $97 \%$ of prosperous US production enterprises based on a Z-score with an annual advance. In the 30 years following the creation of the model, he tested its predictive ability, and another 86 problematic enterprises were analyzed from 1969 to
1975. From 1976 to 1995, Altman tested 110 bankrupt enterprises, and in the period from 1997 to 1999, the number of enterprises went up to 120 . The threshold for problematic businesses was set at 2.67, and businesses were only tested two years before bankruptcy (Maňasová, 2008). Altman (2006) states that the main reason for the higher error rate of the model is that, at that time, US businesses were at higher risk compared to when the model was created. The higher risk level is reflected in the change in the variables $X_{2}$ and $X_{4}$. In 1983, an updated Altman Z-score model was created (for businesses that did not have publicly traded shares) and included the same ratio indicators as the original model. However, the weights of the individual ratio indicators were changed, and thus, the evaluation criteria also changed. The same changes took place in 1995, when a third model was created for the purpose of evaluating non-productive enterprises; it was also used in its own research. Even Altman's models based on multiple discriminant analysis have proved quite successful and stood up to criticism (Pereira et al., 2016). According to Klieštik et al. (2015), the limitations of the models are as follows. The models take only a normal distribution of independent variables into account, consider only homogeneity of the variation-covariation matrix, and assume only a linear relationship between the independent variables. Altman's models are accountingbased, which reduces their ability to predict financial distress and bankruptcy reliably. $\mathrm{Li}$ and Faff (2019) argue that under the goingconcern principle, their application is limited, as predictions of a firm's future financial condition may be less informative when they are based on the firm's past performance.

\section{Tab. 1: Average values of Altman test indicators in 1968}

\begin{tabular}{l|c|c|c}
\multicolumn{2}{c|}{ Indicator } & Healthy enterprises & Bankrupt enterprises \\
\hline Working capital/total assets & $X_{1}$ & 0.414 & -0.061 \\
\hline Retained earnings/total assets & $X_{2}$ & 0.355 & -0.626 \\
\hline Earnings before interest and tax/total assets & $X_{3}$ & 0.154 & -0.318 \\
\hline Market capitalisation/total liabilities & $X_{4}$ & 2.477 & 0.401 \\
\hline Sales/total assets & $X_{5}$ & 1.900 & 1.500 \\
\hline
\end{tabular}




\section{Research Methodology}

After a theoretical overview of the different views on what constitutes an unprosperous enterprise and a specification of the basics of the Altman model, it is possible to define the aim of the presented manuscript as a verification of the Altman model's predictive ability depending on how an unprosperous enterprise is identified.

Based on the theoretical definition of the different views on what highlights an unprosperous enterprise, we present a summary overview (Tab. 2), which also serves to define its own view.

For the purposes of the further analysis of unprosperous enterprises, we will consider ones that meet:

- Separately, one of the four conditions referred to above in the last reference year, 2016 (Variants A1, A2, A3, A4);

- Separately, one of the four conditions referred to above throughout the period under review, in 2014, 2015 and 2016 (Variants B1, B2, B3, B4);

- At the same time, all four of the above conditions in the last reference year, 2016 (Variant C).

Within the framework of the presented research, we discuss the explanatory ability of three variants of the Altman model, i.e., the models from 1968, 1983 and 1995 (for more details and differences, see Kotulič et al., 2018), which are calculated as follows:

$$
\begin{aligned}
& Z_{1968}=1.2 X_{1}+1.4 X_{2}+3.3 X_{3}+0.6 X_{4}+0.999 X_{5} \\
& Z_{1968}=0.717 X_{1}+0.847 X_{2}+3.107 X_{3}+ \\
& +0.420 X_{4}+0.998 X_{5}
\end{aligned}
$$

$$
Z_{1995}=6.56 X_{1}+3.26 X_{2}+6.72 X_{3}+1.05 X_{4}
$$

where: $\quad X_{1}=$ Net working capital/total assets;

$X_{2}=$ Retained earnings/total assets;

$X_{3}=$ Earnings before interest and tax/ total assets;

$X_{4}=$ Market value of equity/total liabilities;

$X_{5}=$ Sales/total assets.

As can be seen from the construction of individual models or modifications of the Altman model, the structure of the indicators used remains the same. Views on their importance has changed over the years, expressed by a change in the weights assigned to each indicator. These changes in weight were subsequently reflected in a change in the intervals/boundaries for the identification of an unprosperous enterprise, or a healthy one, as the case may be (Tab. 3).

The explanatory ability of the Altman model is subsequently verified by the calculation of the type I error $(\alpha)$, type II error $(\beta)$ and overall reliability, which are shown in Tab. 4.

According to Gavúrová et al. (2017) and Delina and Packová (2013), the following calculation is based on the above table for:

- Type I error, i.e., the proportion of misclassified bankrupt companies (the false-negative rate):

\begin{tabular}{|c|c|c|c|c|c|}
\hline \multicolumn{3}{|c|}{ Variant } & \multicolumn{2}{|r|}{ Condition } & \multirow{2}{*}{$\begin{array}{l}\text { Author } \\
\text { Bakeš \& Valášková, 2018; Ďurica, 2018; Valášková et al., } \\
\text { 2018a, 2018b; Bod'a \& Úradníček, 2016; Král' et al., 2016; } \\
\text { Bieliková et al., } 2014\end{array}$} \\
\hline A1 & B1 & \multirow{4}{*}{ C } & 1. & Profit $<0$ & \\
\hline A2 & B2 & & 2. & Equity $<0$ & $\begin{array}{l}\text { Klieštik et al., 2018; Kováčová \& Kubala, 2018; } \\
\text { Mendelová \& Bieliková, 2017; Bod’a \& Úradníček, 2016; } \\
\text { Král' et al., 2016; Bieliková et al., } 2014\end{array}$ \\
\hline A3 & B3 & & 3. & $\mathrm{~L}_{3}<1$ & $\begin{array}{l}\text { Bakeš \& Valášková, 2018; Kováčová \& Kubala, 2018; } \\
\text { Valášková et al., 2018a, 2018b; Bod'a \& Úradníček, 2016; } \\
\text { Král' et al., 2016; Bieliková et al., } 2014\end{array}$ \\
\hline A4 & B4 & & 4. & $\begin{array}{l}\text { EVA }<0 \\
(\text { EAT }- \text { re } \times \text { E) }<0\end{array}$ & $\begin{array}{l}\text { Šofránková et al., 2017; Čámská, 2016; Neumaierová \& } \\
\text { Neumaier, 2013, 2016; Maňasová, } 2008\end{array}$ \\
\hline
\end{tabular}

$$
F N R=\frac{F N}{T P+F N}
$$

\section{Tab. 2: Conditions for identifying an unprosperous enterprise}




\section{Tab. 3: Evaluation boundaries of individual Altman models}

\begin{tabular}{l|c|c|c} 
& Financial problems & Gray zone & Healthy enterprise \\
\hline Z-score (1968)-A68 & $<1.81$ & $<1.81-2.99>$ & $>2.99$ \\
\hline Z-score (1983)-A83 & $<1.2$ & $<1.2-2.9>$ & $>2.9$ \\
\hline Z-score (1995)-A95 & $<1.1$ & $<1.1-2.6>$ & $>2.6$ \\
\hline
\end{tabular}

Source: Bod'a and Úradníček (2016)

\section{Tab. 4: Type I and II error}

\begin{tabular}{l|l|l} 
& \multicolumn{1}{|c|}{ Prediction-bankruptcy } & \multicolumn{1}{c}{ Prediction-non-bankruptcy } \\
\hline Fact-bankruptcy & the correct result (TP) & error type I (FN) \\
\hline Fact-non-bankruptcy & error type II (FP) & the correct result (TN) \\
\hline
\end{tabular}

Source: Klepáč and Hampel (2017)

- Type II error, i.e., the proportion of misclassified prosperous companies (the false-positive rate):

$$
F P R=\frac{F P}{F P+T N}
$$

- Overall reliability (overall accuracy), i.e., the proportion of correctly classified enterprises:

$$
A C C=\frac{T P+T N}{T P+T N+F P+F N}
$$

The data for the analyses were drawn from data for agricultural companies (balance sheets and profit and loss statements) provided by the Ministry of Agriculture of the Slovak Republic in the form of information sheets for anonymous agricultural subjects. The total file included 1,867 subjects of legal and natural persons with up to 19 and 20 or more employees in the period 20142016. By using the SOFINA_standard economic software for financial planning and managerial economy, we identified 996 businesses (from the total set) for which there was a continuous record of financial data for the reference period and which had full records of balance sheets and financial statements (see Fig. 1).

Differences in the economic results of these entities can also be observed with respect to the natural conditions in which they operate. Kotulic et al. (2017) divided the territory of the Slovak Republic into two groups (Fig. 2) on this basis.

\section{Fig. 1: Structure of the research sample}

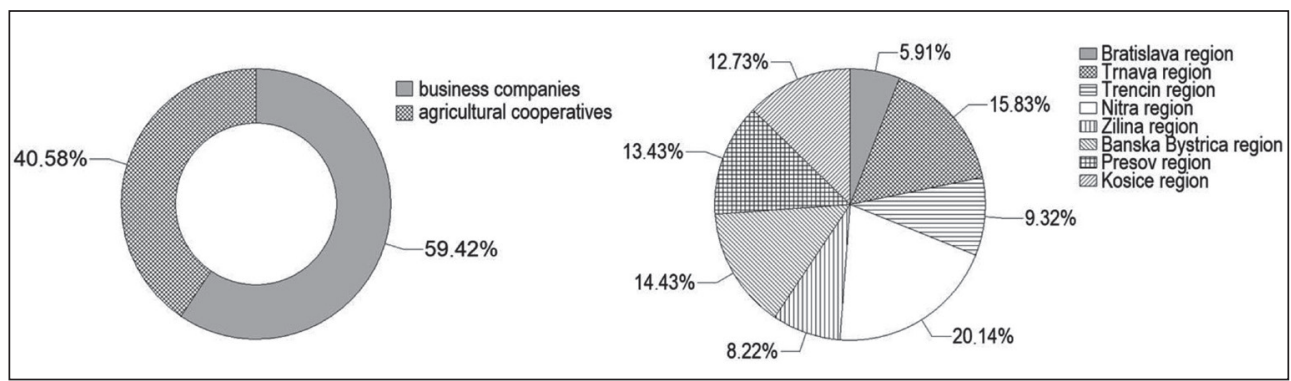




\section{Fig. 2: Spatial distribution of analyzed subjects (LFA - the districts with worse natural conditions; NONLFA - the districts with better natural conditions)}

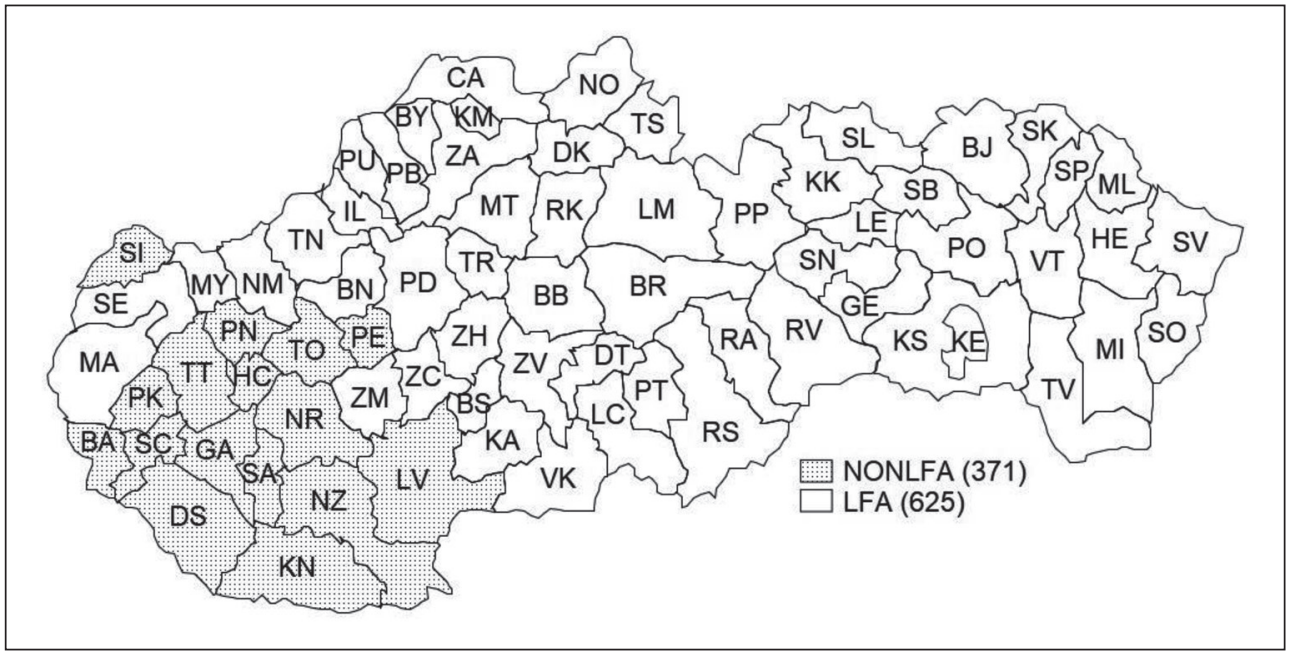

Source: own

The method of Damodaran (2004, 2014) was used to calculate the cost of equity capital (re) according to the EVA indicator (Tab. 2); it was also applied by Šofránková et al. (2017) and Mařík et al. (2011). The analyses were performed in MS Excel, Statistica 13.4 and Statgraphics XVIII.

\subsection{TOPSIS Technique as a Tool for Assessing the Explanatory Ability of the Model}

MCDM (Multi Criteria Decision Making) methods were developed to assist decisionmaking regarding either ranking a known set of alternatives for a problem or making a choice from among this set while considering the conflicting criteria (Mardani et al., 2016). According to Zavadskas et al. (2014), the Technique for Order of Preference by Similarity to Ideal Solution (TOPSIS) is one of the most widely used MCDM methods. The origin of this method can be attributed to Hwang and Yoon (1981) and Yoon (1980), who developed it as an alternative to the ELECTRE method. The result of the TOPSIS technique is described by Streimikine et al. (2012) as a solution with the shortest distance to a positive-ideal solution (PIS), in terms of Euclidean distance. The TOPSIS method offers a solution that is the closest to the abovementioned PIS under the given conditions and, at the same time, the farthest from the negative-ideal solution (NIS) (Zavadskas et al., 2016). The TOPSIS technique was performed according to Vavrek and Bečica (2020) and Vavrek (2019).

The indicators used for the above calculation are the result of an evaluation of the Altman model's explanatory ability:

- $\mathrm{I}_{1}$ = Type $\mathrm{I}$ error (FNR) with a minimizing character;

- $\mathrm{I}_{2}=$ Type II error (FPR) with a minimizing character;

- $\mathrm{I}_{3}=$ Overall reliability $(\mathrm{ACC})$ with a maximizing character.

For each of the MCDM methods, the first and essential step is determining the weights of the individual indicators. Keršuliene et al. (2010) divide the approaches to weighting into four groups: subjective, expert, objective and integrated (which combines the previous approaches). Subjective methods reflect the decision-maker's personality and individual preferences. Objective methods determine weights based on a predetermined mathematical model unique to each method, with the decisionmaker having no influence on the outcome. They include CRITIC (CRiteria Importance Through 
Intercriteria Correlation), MW (mean weight), SD (standard deviation), SVP (Statistical Variance Procedure) and others (see Suder \& Kahraman, 2018; Yalcin \& Unlu, 2018, and others). For our own processing, the Coefficient of variation method (CV) was used, which was devised by Singla et al. (2017) and further described in the studies of Vavrek and Chovancová (2019) and Yalcin and Unlu (2018).

The aim of the CV-TOPSIS combination is an objective assessment of the Altman model's explanatory ability for individual variants, which would reflect the reliability of not only the model (ACC) as a whole but also specific results (FNR and FPR), which we believe should also be considered. These results are supplemented by additional mathematical and statistical methods to which we can add the Mann-Whitney test (W), Kruskal-Wallis test (Q), Levene test (LE) and Kolmogorov-Smirnov test (K-S).

\section{Research Results}

The results of our own research can be divided into several separate parts. In the first, the overall evaluation results are described and statistically compared. In the second, the evaluation of a set of 996 entities is carried out separately using each condition for identifying unprosperous enterprises in the last monitored year, 2016 (i.e., Variants $\mathrm{A} 1, \mathrm{~A} 2, \mathrm{~A} 3, \mathrm{~A} 4)$, one of the conditions for the last three years is fulfilled separately (i.e., Variants B1, B2, B3, B4), and all four conditions for identifying unprosperous enterprises in the last year of the period under review are then fulfilled simultaneously (i.e., Variant C). The last part is a multi-criteria evaluation of the obtained results using the CV-TOPSIS technique.

\subsection{Overall Evaluation Results with the Altman Model}

The variability of the overall evaluation of the results using the variants of the Altman model (from the years 1968, 1983 and 1995) is shown in Fig. 3, from which differences can be identified, especially when comparing the range of variation $\left(R_{A 68}=71.31, R_{A 83}=50.39\right.$, and $R_{A 95}=162.40$ ), which, in combination with the changing subject-classification intervals, underlines overall significant differences $(\mathrm{Q}=26.667 ; \mathrm{p}<0.01$; $\mathrm{LE}=121.036 ; \mathrm{p}<0.01)$. However, the particular variant of the Altman model does not affect the shape of the overall results or their distribution function, because in all three cases, we can consider the results to be positively skewed and more pointed than a normal distribution.

\section{Fig. 3: Overall results of the evaluation of subjects with the Altman model (Z-score)}

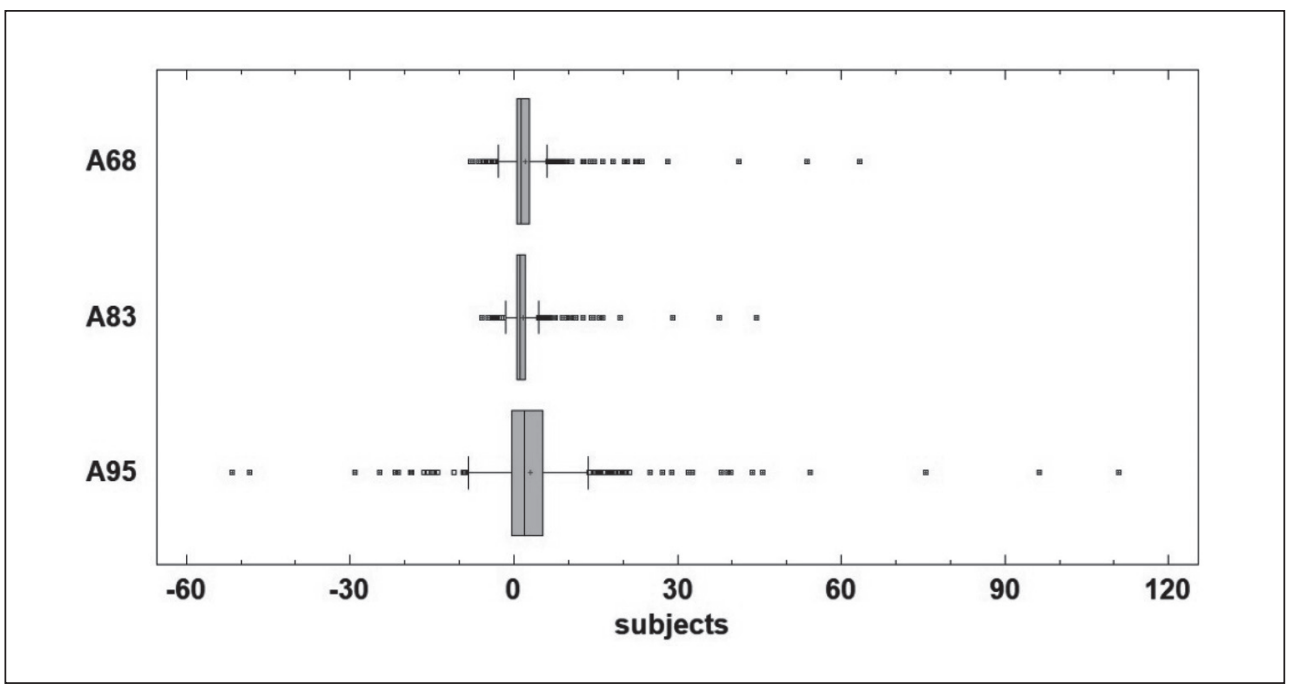




\section{Fig. 4: Classification of the financial health of subjects according to the Altman model}

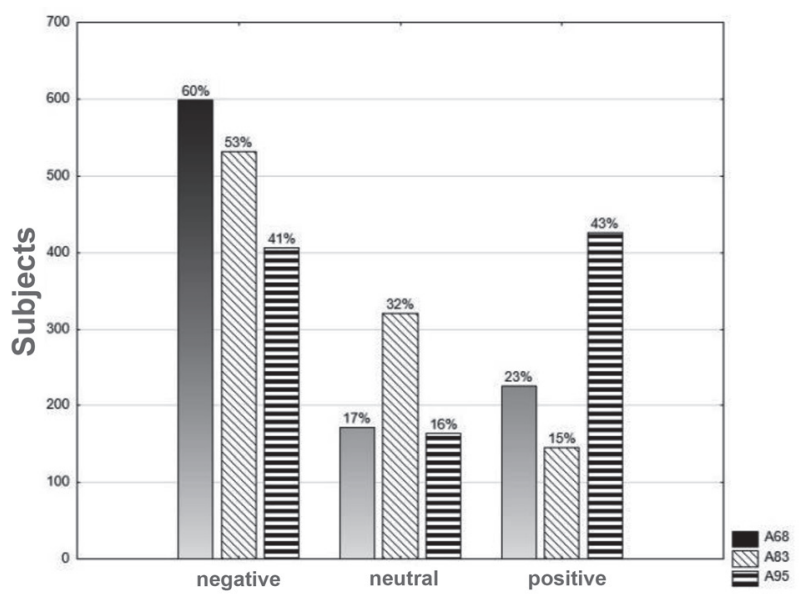

Source: own

This structure of the absolute results is reflected in a classification of the financial health of individual enterprises (Fig. 4). The Altman model from 1968 and 1983 marked the financial health of the majority of the rated entities as negative, and signaled financial problems for these entities in the upcoming period $(60 \%$ or $53 \%$, as the case may be). By contrast, the Altman model from 1995 indicated a satisfactory financial situation for up to $43 \%$ of all the entities (426).

Differences in financial health can also be observed when comparing enterprises operating in better, or worse, natural conditions (LFA/NONLFA). Statistically significant differences were found in the case of the Altman model from 1968 and 1983, when not only the median value but also the overall structure of the results, i.e., their distribution function, was different (see Tab. 5).

The assessment of financial health through variants of the Altman model from 1968 and 1983 is determined by the quality of the soil, i.e., the natural conditions. Statistically significant differences using these variants were also demonstrated in the distribution functions, but we note their homoskedasticity. However, in the case of the 1995 model, the natural conditions did not influence this assessment. Paradoxically, subjects operating in districts with better natural conditions (NONLFA) showed a better average rating. Based on these results, we can say that even in the 21 st century, the assessment of financial health using the Altman

\section{Tab. 5: Comparison of results of the Altman model (LFA/NONLFA)}

\begin{tabular}{c|c|l|l|c|c} 
Model & \multirow{2}{*}{ Medians check } & \multirow{2}{*}{ Variance check } & \multicolumn{2}{c|}{ DF check } & \multicolumn{2}{c}{ Average } \\
\cline { 5 - 7 } & & & & LFA & NON \\
\hline Altman 68 & $\mathrm{W}=131417(<0.01)$ & LE $=0.007(0.934)$ & $\mathrm{K}-\mathrm{S}=1.996(<0.01)$ & 2.37 & 1.99 \\
\hline Altman 83 & $\mathrm{W}=136857(<0.01)$ & $\mathrm{LE}=0.0003(0.985)$ & $\mathrm{K}-\mathrm{S}=2.483(<0.01)$ & 1.90 & 1.51 \\
\hline Altman 95 & $\mathrm{W}=120612(0.287)$ & $\mathrm{LE}=0.039(0.843)$ & $\mathrm{K}-\mathrm{S}=0.910(0.383)$ & 3.18 & 3.08 \\
\hline
\end{tabular}


model is strongly influenced by the variant of the model used. For the purpose of evaluating entities working the soil in the Slovak Republic, we recommend the Altman model from the years 1968 or 1983, which identified previously confirmed differences on the basis of the natural conditions in which the entities operate.

\subsection{Verification of the Explanatory Ability of the Altman Model}

Three variants of the Altman model (from 1968, 1983 and 1995) were used to verify the explanatory ability of the model. The rating is divided according to the method used to identify an unprosperous enterprise, as follows:

- An unprosperous enterprise is one that will separately meet one of the four conditions listed in Tab. 2 in the last reference year, 2016 (variants A1, A2, A3, A4);

- An unprosperous enterprise is one that will separately meet one of the four conditions listed in Tab. 2 throughout the period under review, namely, in 2014, 2015 and 2016 (Variants B1, B2, B3, B4);

- An unprosperous enterprise is one that will meet all four of the conditions listed in Tab. 2 in the last reference year, 2016 (Variant C). When evaluating the first group of results
(Variants A1-A4), it is possible to observe high variability in the obtained results expressed by the variation range and, subsequently, also by the standard deviation or coefficient of variation (Fig. 5). From this point of view, the biggest differences were shown in terms of type I error, i.e., the proportion of misclassified unprosperous enterprises (FNR).

If, as a criterion for identifying an unprosperous enterprise, one indicator is set for the last year, the best results can be obtained by taking into account the third condition, i.e., the negative overall liquidity of the company. Thereby, an overall reliability of almost $80 \%$ can be expected when using the Altman model from $1995(F N R=0.1237 ;$ FPR $=0.1185$; ACC $=0.8795)$. The average values of the monitored parameters when using individual variants of the Altman model are shown in Tab. 6.

Equally, the biggest differences in the second group (Variants B1-B4) can be observed when quantifying the type I error, which, along with overall reliability, is considerably skewed. It can be considered positive in the case of FNR (Fig. 6). For 4 out of the 12 models, the rate of misclassified unprosperous enterprises was below $10 \%$. Like the models in the previous

\section{Fig. 5 :}

5: FNR, FPR and ACC with identification of unprosperous enterprises under variant $A(1-4)$

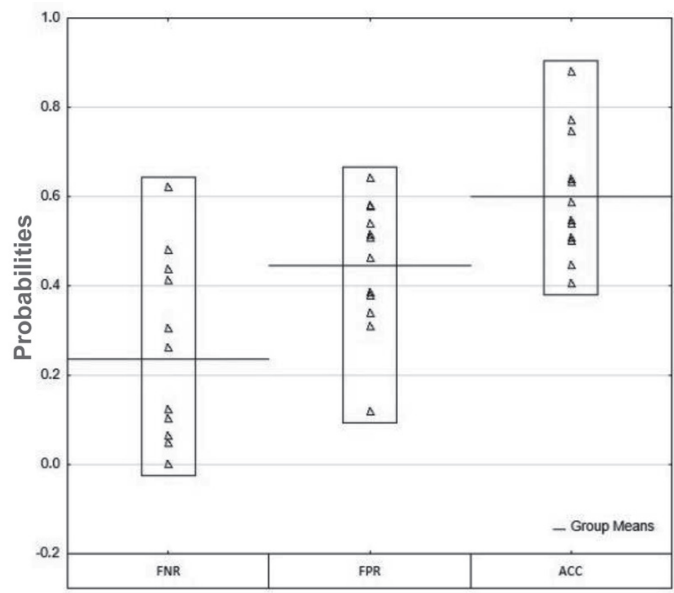




\section{Tab. 6: Differences in FNR, FPR and ACC with identification of unprosperous enterprise under variant $A(1-4)$}

\begin{tabular}{c|c|c|c|c}
\multicolumn{2}{c|}{ Condition } & FNR & FPR & ACC \\
\hline A1 & Profit $<0$ & 0.3344 & 0.4467 & 0.5877 \\
\hline A2 & Equity $<0$ & 0.0213 & 0.4907 & 0.5314 \\
\hline A3 & $\mathrm{L}_{3}<1$ & 0.0912 & 0.2700 & 0.7982 \\
\hline A4 & EVA $<0$ & 0.5032 & 0.5752 & 0.4812 \\
\hline
\end{tabular}

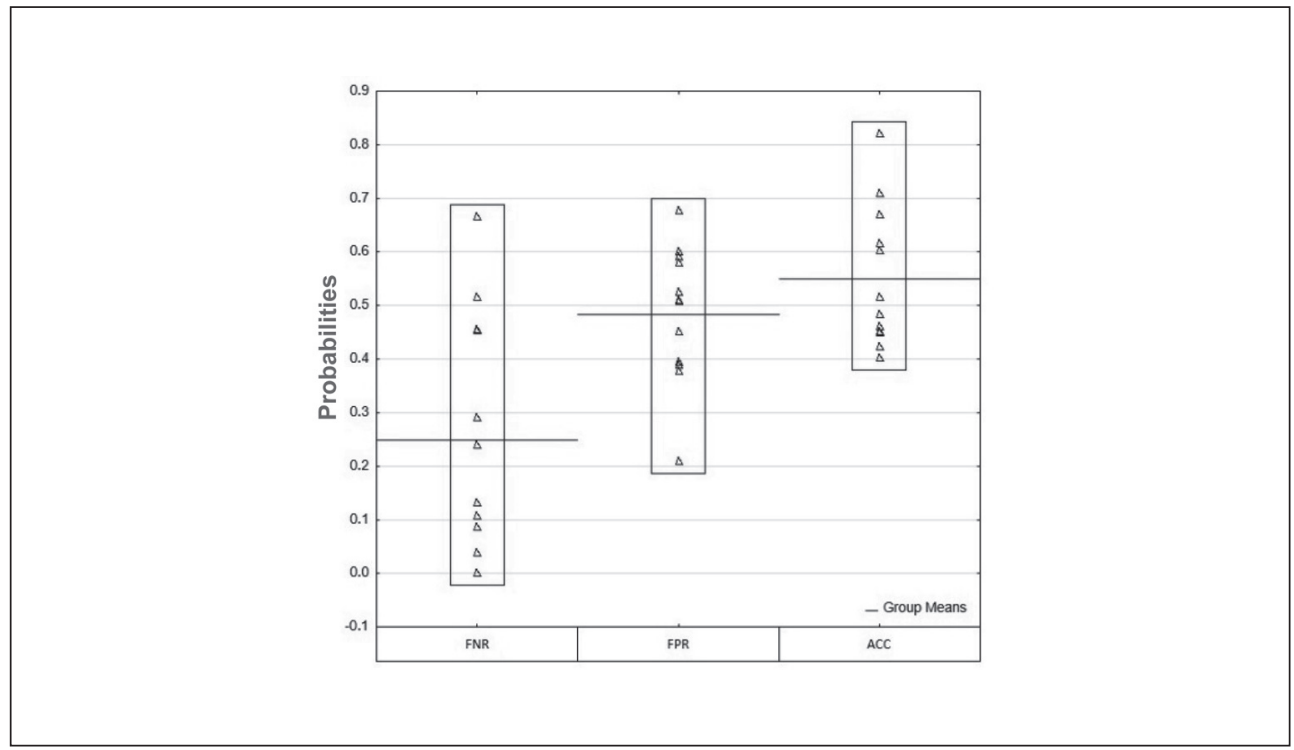

group, even in this case, there is a frequent error in classifying prosperous enterprises, whereby at least $20.82 \%$ of businesses are badly labeled in this way.

If we follow the years 2014, 2015 and 2016 when identifying unprosperous enterprises, the overall reliability of the Altman model does not exceed $75 \%$ in any case. The fourth criterion, the EVA indicator, was clearly inappropriate. In most cases, the model using the EVA indicator also incorrectly identified a bankrupt company as a prosperous enterprise (Tab. 7). Within this group, the Altman model from 1995 achieved the best scores (FNR $=0.1069, \mathrm{FPR}=0.2082$ and $A C C=0.8213)$. The average values of the monitored parameters when using individual variants of the Altman model are shown in Tab. 7.

Monitoring all four indicators during the last year (Variant $\mathrm{C}$, the most difficult variant) showed a low type I error, which did not exceed $5 \%$. However, the problem within this group was the high error rate in identifying prosperous enterprises, which was also reflected in the low overall reliability of the model (Fig. 7). 
Tab. 7: Differences in FNR, FPR and ACC with identification of unprosperous enterprise under variant $B$ (1-4)

\begin{tabular}{c|c|c|c|c}
\multicolumn{2}{c|}{ Condition } & FNR & FPR & ACC \\
\hline B1 & Profit $<0$ & 0.3276 & 0.4930 & 0.5264 \\
\hline B2 & Equity $<0$ & 0.0435 & 0.5032 & 0.5074 \\
\hline B3 & $\mathrm{L}_{3}<1$ & 0.0770 & 0.3456 & 0.7326 \\
\hline B4 & EVA $<0$ & 0.5451 & 0.5944 & 0.4341 \\
\hline
\end{tabular}

Source: own

\section{Fig. 7:}

FNR, FPR and ACC with identification of unprosperous enterprise according to variant $C$

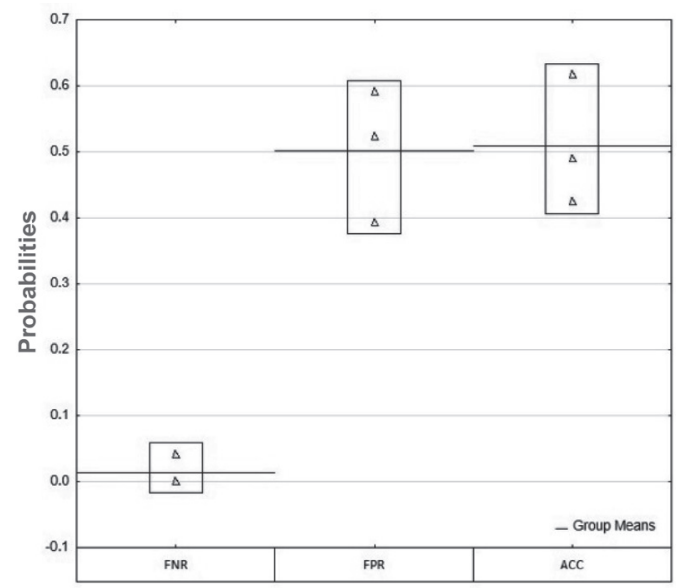

Source: own

\subsection{Common Multi-criteria Evaluation of the Altman Model's Explanatory Ability}

The differences resulting from the method of defining an unprosperous enterprise were described in the previous chapter. Here, we identified the combinations with a lower type I error, i.e., the proportion of misclassified enterprises in bankruptcy (FNR) or lower type II error, i.e., the proportion of misclassified prosperous enterprises (FPR) or higher overall reliability $(A C C)$. To clearly identify the best combination for the needs of enterprises working the soil in the Slovak Republic, it is necessary to take into account all the above attributes simultaneously. To this end, a total of 27 variants were evaluated together.

The overall variability of the input indicators mirrored the partial variability described in the previous section. The biggest differences can again be observed in the case of type I error $\left(\mathrm{s}_{\mathrm{FNR}}=0.2140\right)$; the variability of the other two indicators was similar for both a relative and absolute assessment. The majority group had a below-average FNR and ACC, and an aboveaverage FPR (Fig. 8). 


\section{Finance}

\section{Fig. 8: FNR, FPR and ACC as input criteria for the CV-TOPSIS technique}

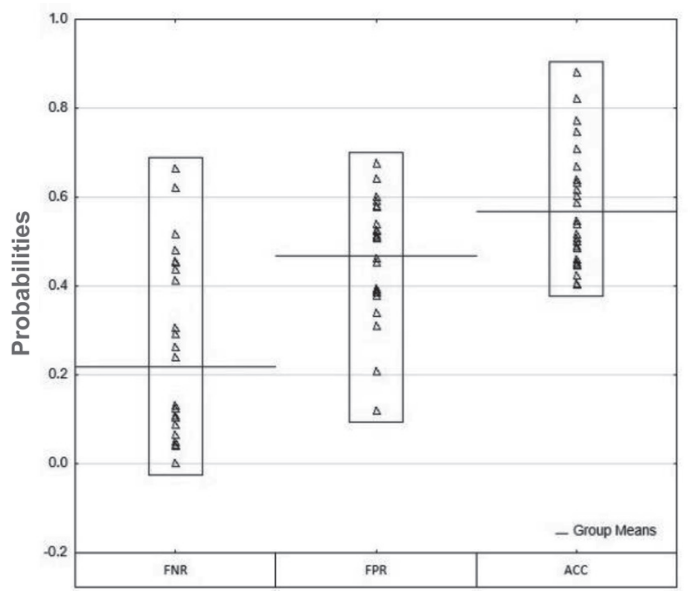

Significant differences found in the overall assessment of the combinations can be confirmed by CV-TOPSIS (Fig. 9). Two combinations did not reach a 0.1 relative distance from the PIS alternative, and one-third of them achieved $c_{i}>0.8$.
The best results are obtained using the negative total liquidity $\left(L_{3}\right)$ as an indicator for identifying an unprosperous enterprise in one year (A3) as well as three years (B3). The results thus obtained are balanced, i.e., their variability is

\section{Fig. 9: Quantile plot of CV-TOPSIS results}

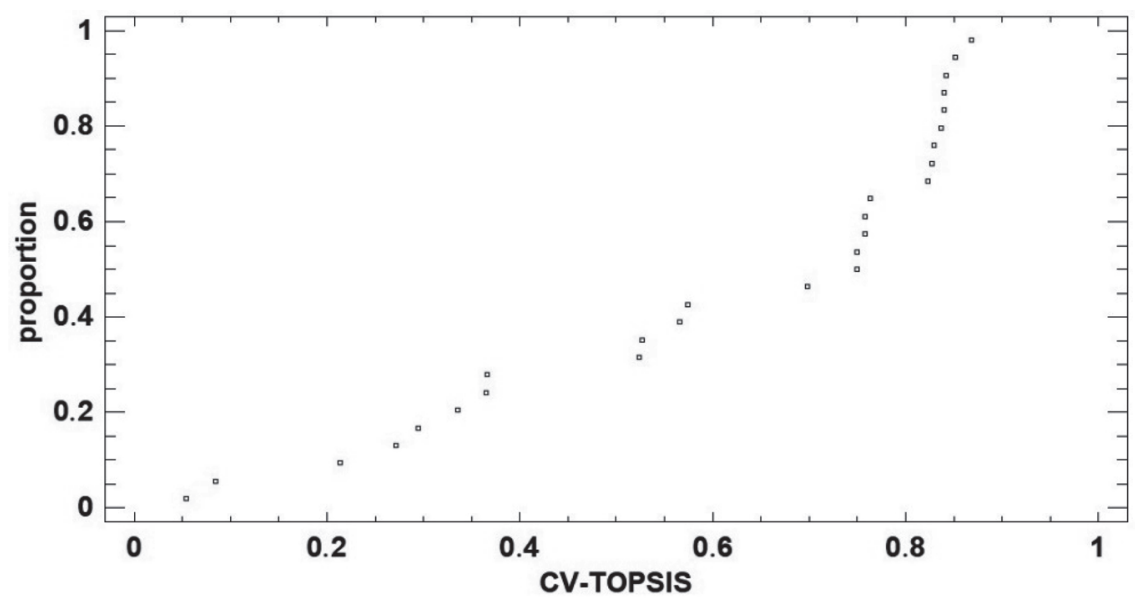




\section{Fig. 10: CV-TOPSIS results distributed according to the determination of an unprosperous enterprise}

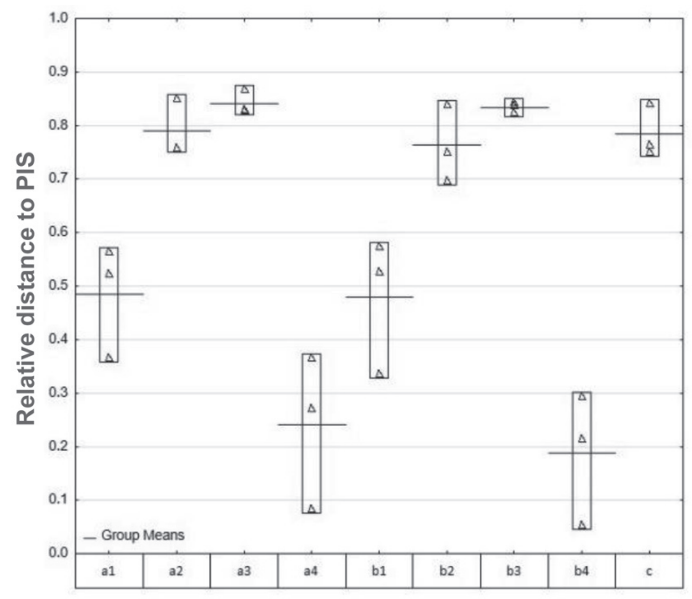

Source: own

the smallest, while the differences between the Altman model variants used are minimal (Fig. 10).

Good overall results $\left(c_{i}\right)$ are also achieved using negative equity, as well as monitoring all the indicators simultaneously $(\mathrm{C})$. In this case, the Altman model used already represents a factor affecting the overall results (see Tab. 8).
The best rated criterion for identifying an unprosperous enterprise was the Altman model from 1968 combined with the monitoring of negative total liquidity $\left(L_{3}\right)$ in the last year. This combination produced a low proportion of misidentified enterprises in decline and had a relatively high overall reliability. The

\section{Tab. 8: Overall results of the CV-TOPSIS technique}

\begin{tabular}{c|l|l|l|l|l|l} 
Rank & Model & A $^{*}$ & FNR & FPR & ACC & $\mathbf{c}_{\mathbf{i}}$ \\
\hline 1 & Altman 68 & A3 & 0.0473 & 0.3831 & 0.7449 & 0.8682 \\
\hline 2 & Altman 95 & A2 & 0 & 0.3782 & 0.6395 & 0.8512 \\
\hline 3 & Altman 95 & B3 & 0.1068 & 0.2082 & 0.8212 & 0.8420 \\
\hline 4 & Altman 95 & C & 0 & 0.3930 & 0.6164 & 0.8402 \\
\hline 5 & Altman 95 & B2 & 0 & 0.3936 & 0.6154 & 0.8397 \\
\hline 6 & Altman 68 & B3 & 0.0379 & 0.4518 & 0.6686 & 0.8368 \\
\hline 7 & Altman 83 & A3 & 0.1026 & 0.3084 & 0.7700 & 0.8295 \\
\hline 8 & Altman 95 & A3 & 0.1236 & 0.1185 & 0.8795 & 0.8272 \\
\hline 9 & Altman 83 & B3 & 0.0862 & 0.3767 & 0.7078 & 0.8234 \\
\hline 10 & Altman 83 & C & 0.0416 & 0.5226 & 0.4889 & 0.7627 \\
\hline
\end{tabular}

Note: * a precondition for identifying an unprosperous enterprise. 
combinations of the Altman model with indicators that did not make errors in identifying unsuccessful enterprises were ranked next, but their drawback was their lower overall reliability.

\section{Discussion}

The Altman model is still one of the most commonly used prediction models. When trying to predict two years in advance, the success rate for predicting a business entity's bankruptcy has been 72-94\% (Zwingli \& White, 2010). Yi (2012) states that the Altman Z-score still has a high predictive ability for US companies. The study of Altman et al. (2017) offers evidence that the general Z-score model works reasonably well for most countries (the prediction accuracy is approximately 0.75 ), and the classification accuracy can be improved further (above 0.90 ) by using country-specific estimation that incorporates additional variables.

The use of the Altman Z-score for Slovak enterprises is more than questionable. Its unsuitability for the conditions of Slovak companies has been confirmed by several empirical surveys. In particular, Kabát (2011b) pointed out that the model was derived from the special conditions of the American market; different legislation and content definitions could make its use for Slovak enterprises problematic. Using a sample of 700 Slovak enterprises, Gavúrová et al. (2017) found that the Altman model was less accurate than Czech models, which better reflect the conditions in this region $(\mathrm{FNR}=22.86 \% ; \mathrm{ACC}=77.14 \%)$. From the research of Mihalovič (2018), conducted on a sample of 1,280 enterprises (evenly divided into bankrupt and prosperous enterprises), it can be seen that the model of multidimensional discriminatory analysis exhibited a type I error of up to $54.38 \%$, confirming the unacceptability of using such a model. Delina and Packová (2013) analyzed a sample of 1,560 Slovak enterprises from 1993 to 2007, of which 103 were in bankruptcy during this period. The Altman model showed the worst results. The incorrect prediction of bankruptcy was $87.62 \%$, the accuracy of the prediction of bankruptcy was $12.38 \%$, and the return of the forecast was $51.46 \%$. On this basis, they noted that the Altman model was not suitable for use in the Slovak economy. The aforementioned authors uniformly pointed out that the main drawback was the fact that the model was created in a different, specific environment and time that differs from the current Slovak business environment. On the other hand, Bod'a and Úradníček (2016) argued that the Altman Z-score was suitable for the economic conditions of Slovak enterprises and could be a useful tool for predicting their decline.

\section{Conclusion}

Based on these analyses, we can state that the way of defining an unprosperous enterprise is a significant factor affecting the overall reliability of the Altman model; monitoring a longer period for defining an unprosperous enterprise does not automatically mean better results (reflected in the fact that 4 of the top 10 combinations followed the indicator for more than one year). The Altman model from 1968 and 1983 confirmed the differences resulting from the natural conditions in which the enterprises operate. If the aim of the research is to identify a combination with the smallest type I error, the smallest proportion of misclassified bankrupt enterprises, we recommend using the Altman model from 1968 or 1995, using negative equity as an indicator to monitor, for determining an unprosperous enterprise, i.e., a company in trouble. However, if the aim the research is to identify a combination with the smallest type II error, the smallest proportion of misclassified prosperous enterprises, we recommend using the Altman model from 1995, using negative total liquidity as an indicator to monitor, for determining an unprosperous enterprise. In this case, the enterprise creates uncovered debt, which means that it is undercapitalized, i.e., part of the fixed assets are covered by shortterm resources, and the golden rule of funding is thereby not met. The same combination of the Altman model from 1995 and negative total liquidity can be recommended to achieve the highest overall reliability for the model. The economic results and economic value added (EVA) proved to be inappropriate as indicators for defining an unprosperous enterprise in the conditions of the Slovak Republic.

The above conclusions should be seen within the limits of this research. In our opinion, it is not possible to unequivocally reject or recommend the use of the Altman model for the evaluation of entities working the soil in the Slovak Republic. To supplement this conclusion, it is necessary to identify the explanatory ability of other models, e.g., the Taffler model or Bonity index, which are also often used in 
this region. In addition, we plan, in the future, to verify the predictive abilities of the Gurčík index and Chrastinova model, which were designed expressly for the needs of Slovak farms. Another limitation is the territory of the Slovak Republic. In order to increase the objectivity of the research results, we recommend extending the research sample to subjects working the soil in other V4 countries and comparing them.

Acknowledgments: Supported by the grant No. CZ.02.2.69/0.0/0.0/16_027/0008493 "International mobility of TUL researchers" of the "Ministry of Education, Youth and Sport of the Czech Republic", the grant No. 024PU-4/2020 "Innovation of the structure, content and way of teaching economic subjects for the study program Management and Environmental Management at the PhD level" of the "Cultural and Educational Grant Agency of the Ministry of Education, Science, Research and Sport of the Slovak Republic", the grant No. 1/0578/18 "Modification of methodologies for sustainable assessment and management" of the "Scientific Grant Agency of the Ministry of Education, Science, Research and Sport of the Slovak Republic and the Slovak Academy of Sciences".

\section{References}

Alaka, H. A., Oyedele, L. M., Owolabi, H. A., Kumar, V., Ajayi, S. O., Akinade, O. O., \& Bilal, M. (2018). Systematic review of bankruptcy prediction models: Towards a framework for tool selection. Expert Systems with Application, 94, 164-184. https://doi.org/10.1016/j. eswa.2017.10.040

Almamy, J., Aston, J., \& Ngwa, L. N. (2016). An evaluation of Altman's Z-score using cash flow ratio to predict corporate failure amid the recent financial crisis: Evidence from the UK. Journal of Corporate Finance, 36, 278-285. https://doi.org/10.1016/j.jcorpfin.2015.12.009

Altman, E. I. (2002). Bankruptcy, credit risk, and high yield junk bonds. Malden: Blackwell.

Altman, E. I., \& Hotchkiss, E. (2006). Corporate Financial Distress and Bankruptcy: Predict and Avoid Bankruptcy, Analyze and Invest in Distressed Debt. New York, NY: Wiley. http://doi.org/10.1002/9781118267806

Altman, E. I. (1968). Financial Ratios, Discriminant Analysis and the Prediction of Corporate Bankruptcy. The Journal of Finance, 23(4), 589-609. https://doi. org/10.1111/j.1540-6261.1968.tb00843.x
Altman, E. I., Iwanicz-Drozdowska, M., Laitinen, E. K., \& Suvas, A. (2017). Financial Distress Prediction in an International Context: A Review and Empirical Analysis of Altman's Z-score Model. Journal of International Financial Management \& Accounting, 28(2), 131-171. https://doi.org/10.1111/jifm.12053

Antunes, F., Ribeiro, B., \& Pereira, F. (2017). Probabilistic modelling and visualization for bankruptcy prediction. Applied Soft Computing, 60, 831-843, https://doi.org/10.1016/j. asoc.2017.06.043

Bakeš, V., \& Valášková, K. (2018). Application and verification of Slovak prediction models in conditions of national economy. Podniková ekonomika a manažment. Elektronický časopis o ekonomike, manažmente, marketingu a logistike podniku, 2, 3-15.

Balcaen, S., \& Ooghe, H. (2006). 35 years of studies on business failure: An overview of the classic statistical methodologies and their related problems. The British Accounting Review, 38(1), 63-93. http://doi.org/10.1016/j.bar.2005.09.001

Bank, V., Tarasquina, A., \& Bank, S. (2006). Financial analysis. Moscow: Prospect.

Belas, J., Cipovova, E., Novak, P., \& Polach, J. (2012). Impacts of the Foundation Internal Ratings Based Approach Usage on Financial Performance of Commercial Bank. E\&M Economics and Management, 15(3), 142-154.

Bieliková, T. (2016). Inovatívne možnosti diagnostikovania finančného zdravia výrobného podniku vo väzbe na jeho finančno-ekonomickú výkonnost'. Banská Bystrica: EF UMB.

Bieliková, T., Cút, S., \& Úradníček, V. (2014). The influence of the definition of risky company on financial situation diagnostic models in Slovak dynamic economic environment. In M. Čulík (Ed.), Managing and modelling of financial risks: Proceedings from 7th international scientific conference (pp. 38-45). Ostrava: VSB - Technical University of Ostrava.

Bocharov, V. (2007). Financial analysis. Saint Petersburg: Peter Press.

Bod'a, M., \& Úradníček, V. (2016). The portability of Altman's Z-score model to predicting corporate financial distress of Slovak companies. Technological and Economic Development of Economy, 22(4), 532-553. https://doi.org/10.3846/20294913.2016.1197165

Bod'a, M., \& Úradníček, V. (2019). Predicting Financial Distress of Slovak Agricultural Enterprises. Ekonomický časopis, 67(4), 426-452. 
Brealey, R. A., Myers, S. C., \& Allen, F. (2011). Principles of Corporate Finance. New York, NY: McGraw-Hill/lrwin.

Čámská, D. (2016). Accuracy of Models Predicting Corporate Bankruptcy in a Selected Industry Branch. Ekonomický časopis, 64(4), 353-366.

Čámská, D., \& Klecka, J. (2020). Comparison of Prediction Models Applied in Economic Recession and Expansion. Journal of Risk and Financial Management, 13(3), 1-16, https://doi.org/10.3390/jrfm13030052

Damodaran, A. (2004). Valuation the Big Picture. Retrieved October 10, 2019, from http://people.stern.nyu.edu/adamodar/pdfiles/ country/BrazilJune04.pdf

Damodaran, A. (2014). Equity Risk Premiums: Looking Backwards and Forwards. Retrieved October 15, 2019, from http://people. stern.nyu.edu/adamodar/pdfiles/country/ERP.pdf

Delina, R., \& Packová, M. (2013). Prediction bankruptcy models validation in Slovak business environment. E\&M Economics and Management, 16(3), 101-110.

Duurica, M. (2018). Decision Tree Financial Distress Prediction Model for Slovak Companies. Podniková ekonomika a manažment, 2, 16-26.

Gavúrová, B., Packová, M., Mišanková, M., \& Smrčka, L'. (2017). Predictive potential and risks of selected bankruptcy prediction models in the Slovak business environment. Journal of Business Economics and Management, 18(6), 1156-1173. https://doi.org/10.3846/16111699.2 017.1400461

Hosaka, T. (2019). Bankruptcy prediction using imaged financial ratios and convolutional neural networks. Expert Systems with Application, 117, 287-299.

Hwang, C.-L., \& Yoon, K. (1981). Multiple Attribute Decision Making Methods and Applications: A State-of-the-Art Survey. Berlin, Heidelberg: Springer-Verlag.

Kabát, L. (2011a). Ako d’alej v aplikácii Altmanovho modelu? Finančný manažér, 11(1), 7-9.

Kabát, L.(2011b). Problémyaplikáciebonitných a predikčných modelov $v$ podnikatel'skom prostredí SR. Finančný manažér, 11(3), 89-90.

Karas, M., \& Řežnáková, M. (2012). Financial Ratios as Bankruptcy Predictors: The Czech Republic Case. In D. Pavelková, J. Strouhal, \& M. Pasekova (Eds.), Proceeding of the 1st WSEAS International Conference on Finance, Accounting and Auditing (pp. 56-67). Athen: WSEAS.
Keršuliene, V., Zavadskas, E. K., \& Turskis, Z. (2010). Selection of rational dispute resolution method by applying new step-wise weight assessment ratio analysis (SWARA). Journal of Business Economics and Management, 11(2), 1611-1699. https://doi.org/10.3846/ jbem.2010.12

Klepáč, V., \& Hampel, D. (2017). Predicting financial distress of agriculture companies in EU. Agricultural Economics, 63(8), 347-355. https://doi.org/10.17221/374/2015-AGRICECON

Klieštik, T., Kočišová, K., \& Mišanková, M. (2015). Logit and Probit Model used for Prediction of Financial Health of Company. Procedia Economics and Finance, 23, 850-855.

Klieštik, T., Mišanková, M., Valašková, K., \& Svabová, L. (2018). Bankruptcy Prevention: New Effort to Reflect on Legal and Social Changes. Science and Engineering Ethics, 24(2), 791-803. http://doi.org/10.1007/s11948017-9912-4

Kliestik, T., Valaskova, K., Lazaroiu, G., Kovacova, M., \& Vrbka, J. (2020). Remaining Financially Healthy and Competitive: The Role of Financial Predictor. Journal of Competitiveness, 12(1), 74-92, https://doi. org/10.7441/joc.2020.01.05

Ko, Y. C., Fujita, H., \& Li, T. (2017). An evidential analysis of Altman Z-score for financial predictions: case study on solar energy companies. Applied Soft Computing, 52, 748759. https://doi.org/10.1016/j.asoc.2016.09.050

Kočišová, K., \& Mišanková, M. (2014). Discriminant Analysis as a Tool for Forecasting Company's Financial Health. Procesia - Social and Behavioral Sciences, 110, 1148-1157. https://doi.org/10.1016/j.sbspro.2013.12.961

Kotulič, R., Adamišin, P., Kravčáková Vozárová, I., \& Vavrek, R. (2017). The impact of management skills of agricultural entities in relation to economic efficiency and NaturalClimatic conditions in Slovakia. Journal of Environmental Management and Tourism, 8(1), 92-99. https://doi.org/10.14505//jemt.v8.1(17).09

Kotulič, R., Király, P., \& Rajčániová, M. (2018). Finančná analýza podniku. Bratislava: Wolters Kluwer SR.

Kováčová, M., \& Kubala, P. (2018). Verification of Prediction Models Based on Discriminant Analysis in Conditions of Slovak Republic. Podniková ekonomika a manažment, 2, 52-64.

Král', P., Fleischer, M., Stachová, M., \& Nedelová, G. (2016). Corporate financial 
distress prediction of Slovak companies: Z-score models vs. alternatives. In M. Bod'a, V. Mendelová (Eds.), AMSE 2016 - 19th Applications of Mathematics and Statistics in Economics Conference Proceedings (pp. 224231). Banská Štiavnica: UMB.

Le, T., Lee, M. Y., Park, J. R., \& Baik, S. W. (2018). Oversampling techniques for bankruptcy prediction: Novel features from a transaction dataset. Symmetry-Basel, 10(4), 1-13. https://doi.org/10.3390/sym10040079

Lesáková, L., Elexa, L'., \& Gundová, P. (2015). Finančno-ekonomická analýza podniku 2. Banská Bystrica: UMB.

Li, L., \& Faff, R. (2019). Predicting corporate bankruptcy: What matters? International Review of Economics and Finance, 62, 1-19.

Lifschutz, S., \& Jacobi, A. (2010). Predicting bankruptcy: evidence from Israel. International Journal of Business and Management, 5(4), 133-141. https://doi.org/10.5539/ijbm.v5n4p133

Maňasová, Z. (2008). Úpadky podniků $v$ České republice a možnosti jejich včasné predikce. Prague: Prague University of Economics and Business.

Mardani, A., Zavadskas, E. K., Govindan, K., Senin, A. A., \& Jusoh, A. (2016). VIKOR Technique: A Systematic Review of the State of the Art Literature on Methodologies and Applications. Sustainability, 8(1), 1-38. https://doi.org/10.3390/su8010037

Mařík, M., Čada, K., Dušek, D., Maříková, P., Rýdlová, B., \& Rajdl, J. (2011). Metody oceňování podniku: proces ocenění - základní metody a postupy. Prague: Ekopress.

Megginson, W. L., Meles, A., Sampagnaro, G., \& Verdoliva, V. (2019). Financial Distress Risk in Initial Public Offerings: How Much Do Venture Capitalists Matter? Journal of Corporate Finance, 59, 10-30. https://doi. org/10.1016/j.jcorpfin.2016.09.007

Mendelová, V., \& Bieliková, T. (2017). Diagnostikovanie finančného zdravia podnikov pomocou metódy DEA: Aplikácia na podniky v Slovenskej Republike. Politická ekonomie, 65(1), 26-44. https://www.doi.org/10.18267/j. polek. 1125

Mihalovič, M. (2018). Využitie skóringových modelov při predikcii úpadku ekonomických subjektov v Slovenskej republike. Politická ekonomie, 66(6), 689-708. https://doi. org/10.18267/j.polek.1226

Mrkvička, J., \& Kolář, P. (2006). Financial analysis. Prague: ASPI.
Neumaierová, I., \& Neumaier, I. (2013). Vypovídací schopnost Indexu IN05. In Ekonomika $v$ pohybu: Sborník príspěvků $z$ mezinárodní konference pořádané u príležitosti šedesátého výročí VŠE a fakulty [Economy in motion: Proceedings from the international conference organized on the occasion of the 60th anniversary of University of Economics and the faculty] (pp. 169-176). Prague: Prague University of Economics and Business.

Neumaierová, I., \& Neumaier, I. (2016). The Performance Ranking of Chosen Manufacturing Division. In J. Krajíček, J. Nešleha, \& K. Urbanovský (Eds.), 13th International Scientific Conference of the European Financial Systems (pp. 502-507). Brno: Masaryk University.

Pereira, J., Basto, M., \& da Silva, A. (2016). The Logistic Lasso and Ridge Regression in Predicting Corporate Failure. Procedia Economics and Finance, 39, 634-641.

Pitrová, K. (2011). Possibilities of the Altman Zeta Model Application to Czech Firms. E\&M Economics and Management, 14(3), 66-76.

Rahman, A., Belas, J., Kliestik, T., \& Tyll, L. (2017). Collateral requirements for SME loans: empirical evidence from the Visegrad countries. Journal of Business Economics and Management, 18(4), 650-675. https://www.doi. org/10.3846/16111699.2017.1357050

Režnáková, M., \& Karas, M. (2015). The prediction capabilities of bankruptcy models in a different environmnet: an example of the Altman Model under the conditions in the Visegrad group countries. Ekonomický časopis, 63(6), 617-633.

Schönfeld, J., Kuděj, M., \& Smrčka, L. (2018). Financial health of enterprises introducing safeguard procedure based on bankruptcy models. Journal of Business Economics and Management, 19(5), 692-705. https://doi.org/10.3846/jbem.2018.7063

Singla, A., Sing Ahuja, I., \& Sing Sethi, A. (2017). Comparative Analysis of Technology Push Strategies Influencing Sustainable Development in Manufacturing Industries Using Topsis and Vikor Technique. International Journal for Quality Research, 12(1), 129-146. https://doi.org/10.18421/IJQR12.01-08

Šofránková, B., Kiseláková, D., \& Horváthová, J. (2017). Actual questions of risk management in models affecting enterprise performance. Ekonomický časopis, 65(7), 644-667. 
Streimikiene, D., Balezentis, T., Krisciukaitiene I., \& Balezentis, A. (2012). Prioritizing sustainable electricity production technologies: MCDM approach. Renewable \& Sustainable Energy Reviews, 16(5), 33023311. https://doi.org/10.1016/j.rser.2012.02.067

Suder, A., \& Kahraman, C. (2018). Multiattribute evaluation of organic and inorganic agricultural food investments using fuzzy TOPSIS. Technological and Economic Development of Economy, 24(3), 844-858. https://doi.org/10.3846/20294913.2016.1216905.

Sulub, S. A. (2014). Testing the predictive power of Altman's revised Z-model: The case of 10 multinational companies. Research Journal of Finance and Accounting, 5(21), 174-184.

Sun, J., Li, H., Huang, Q. H., \& He, K. Y. (2014). Predicting financial distress and corporate failure: a review from the state-ofthe-art definitions, modeling, sampling, and featuring approaches. Knowledge-Based Systems, 57, 41-56. http://doi.org/10.1016/j. knosys.2013.12.006

Sušický, J. (2011). Využitelnost bankrotních modelů a jejich aplikace $v$ podmínkách České Republiky. Prague: Czech University of Life Sciences Prague.

Sůvová, H., \& Knaifl, O. (2008). Finanční analýza I. Prague: Ambis College.

Valášková, K., Klieštik, T., \& Kováčová, M. (2018). Management of financial risks in Slovak enterprises using regression analysis. Oeconomia Copernicana, 9(1), 105-121. https://doi.org/10.24136/oc.2018.006

Valáškova, K., Klieštik, T., Švabová, L., \& Adamko, P. (2018). Financial Risk Measurement and Prediction Modelling for Sustainable Development of Business Entities Using Regression Analysis. Sustainability, 10(7), 1-15. https://doi.org/10.3390/su10072144

Vavrek, R. (2019). Evaluation of the Impact of Selected Weighting Methods on the Results of the TOPSIS Technique. International Journal of Information Technology \& Decision Making, 18(6), 1821-1843. https://doi.org/10.1142/ S021962201950041X

Vavrek, R., \& Chovancová, J. (2019). Assessment of economic and environmental energy performance of EU countries using CV-TOPSIS technique. Ecological Indicators, 106, 105519. https://doi.org/10.1016/j. ecolind.2019.105519

Vavrek, R., \& Bečica, J. (2017). Capital City as a Factor of Multi-Criteria Decision Analysis - Application on Transport Companies in the Czech Republic. Mathematics, 8(10), 1765. http://doi.org/10.3390/math8101765

Yalcin, N., \& Ünlü, U. (2018). A Multi-Criteria Performance Analysis of Initial Public Offering (IPO) Firms Using Critic and Vikor Methods. Technological and Economic Development of Economy, 24(2), 534-560. https://doi.org/10.38 46/20294913.2016.1213201

Yi, W. (2012). Z-score Model on Financial Crisis Early Warning of Listed Real Estate Companies in China: A Financial Engineering Perspective. Systems Engineering Procedia, 3, 153-157. https://doi.org/10.1016/j.sepro.2011.11.021

Yoon, K. (1980). Systems selection by multiple attribute decision making. Manhattan, KS: Kansas State University.

Zalai, K. et al. (2013). Finančno-ekonomická analýza podniku. Bratislava: Sprint 2.

Zavadskas, E. K., Mardani, A., Turskis, Z., Jusoh A., \& Nor, K. (2016). Development of TOPSIS Method to Solve Complicated Decision-Making Problems: An Overview on Developments. From 2000 to 2015. International Journal of Information Technology \& Decision Making, 15(03), 1-38. http://doi. org/10.1142/S0219622016300019

Zavadskas, E. K., Turskis, Z., \& Kildienè, S. (2014). State of art surveys of overviews on MCDM/MADM methods. Technological and Economic Development of Economy, 20(1), 165-179. https://doi.org/10.3846/20294913.20 14.892037

Zelenkov, Y., Fedorova, E., \& Chekrizov, D. (2017). Two-step classification method based on genetic algorithm for bankruptcy forecasting. Expert Systems with Applications, 88, 393-401. https://doi.org/10.1016/j.eswa.2017.07.025

Zwingli, J., \& White, T. (2010). Can you trust your credit model? Credit and Financial Management Review, 16(2), 33-42. 